\title{
PEMBERDAYAAN GELANDANGAN DAN PENGEMIS MELALUI BIMBINGAN VOKASI DI BALAI REHABILITASI UNIT BINA KARYA YOGYAKARTA
}

\author{
NOVIE PURNIA PUTRI, MUNIFATUZ ZAHRO' \\ UIN Sunan Kalijaga Yogyakarta, Indonesia \\ Email: novieppurniapp@gmail.com
}

\begin{abstract}
Bum and beggars are one of the social welfare problems in Yogyakata. In the rehabilitation program for sprawl, the Bina Karya unit has a one-year program target for fifty fostered residents with an on-off system, where there is a certain period of sprawl getting fostered until the termination stage. This research discusses the empowerment of homeless people and beggars through vocational guidance at the Center of Rehabilitation of Unit Bina Karya in Yogyakarta. This type of research uses a qualitative approach. The results of this study indicate that the vocational guidance provided by Balai for flat housing includes welding, wood, sewing, and agriculture vocational guidance. In the implementation of vocational guidance has supporting and inhibiting factors. The supporting factors such as cooperation with Balai practitioners who are competent in their fields and collaborating with business units. Then the inhibiting factors include the mental and mindset of the Social Fostered Citizens (WBS) are weak, WBS rejection of guidance, lack of social workers, and vocational assessment is less in-depth.
\end{abstract}

Keywords: Vocational; Socially Assisted Citizens.

\begin{abstract}
Abstrak. "Gepeng" adalah satu dari sekian masalah sosial yang ada di Yogyakarta. Dalam program rehabilitasi terhadap Gepeng, unit Bina Karya memiliki sasaran program satu tahun untuk lima puluh warga binaan dengan sistem on-off, di mana terdapat periode tertentu terhadap Gepeng untuk mendapatkan binaan sampai pada tahap terminasi. Melalui metode kualitatif, penelitian ini membahas pemberdayaan gelandangan dan pengemis melalui bimbingan vokasi di Balai Rehabilitasi Unit Bina Karya Yogyakarta. Hasilnya menunjukkan bimbingan vokasi oleh Balai terhadap gepeng meliputi bimbingan vokasi las, kayu, menjahit, dan pertanian. Dalam pelaksanaan bimbingan vokasi ada beberapa faktor pendukung dan penghambat. Faktor pendukung meliputi kerjasama Balai dengan praktisi yang kompeten dalam bidangnya dan bekerja sama dengan unit usaha. Sedangkan faktor penghambat meliputi mental dan mindset Warga Binaan Sosial (WBS) yang lemah, penolakan WBS terhadap bimbingan, kurangnya tenaga pekerja sosial, dan assessment vokasional kurang mendalam.
\end{abstract}

Kata Kunci: Vokasional; Warga Binaan Sosial. 


\section{PENDAHULUAN}

Di Indonesia, fenomena "gepeng" (gelandangan dan pengemis) menjadi permasalahan sosial yang harus diperhatikan secara khusus. Mudahnya akses gelandangan dan pengemis dalam mencari uang di jalanan terutama di perkotaan seperti Yogyakarta menjadi daya tarik tersendiri bagi mereka tanpa perlu mempersiapkan bekal keterampilan serta pendidikan yang memadai. Badan Pusat Statistik (BPS) Yogyakarta menyebutkan bahwa pada tahun 2015 terdapat 74 anak jalanan dan orang terlantar yang mendapat bantuan Pemerintah Provinsi Yogyakarta. Ini salah satu langkah pemerintah dalam mengurangi jumlah "gepeng" terutama di Kota Yogyakarta.

PP. No. 3 Tahun 1990 menyebut gelandangan sebagai orang-orang yang hidup dalam keadaan yang tidak sesuai dengan norma kehidupan yang layak dalam masyarakat setempat, tidak mempunyai mata pencaharian dan tempat tinggal yang tetap, serta hidup mengembara di tempat umum. Sedangkan PP. No. 31 Tahun 1980 menyebut pengemis sebagai orang-orang yang mendapatkan penghasilan dengan meminta-minta di tempat umum dengan berbagai cara dan alasan untuk mengharap belas kasihan orang lain.

Perda No. 6/2011 menyebut bahwa anak-anak yang hidupnya di jalanan terutama di Yogyakarta, maka mereka memperoleh perlindungan. Dalam perda tersebut, perlindungan yang dimaksud adalah segala tindakan untuk menjamin dan melindungi anak dan hak-haknya agar dapat hidup, tumbuh, berkembang, dan berpartisipasi secara optimal sesuai dengan harkat dan martabat kemanusiaan, mendapat perlindungan dan diskriminasi, eksploitasi dan kekerasan melalui rangkaian upaya sehingga anak terentaskan dari kehidupan di jalan.

Dalam proses perlindungan gelandangan dan pengemis, terdapat upaya pemberdayaan masyarakat yang diyakini sebagai alternatif dalam memandirikan masyarakat melalui perwujudan potensi dan kemampuan yang mereka miliki. Gunawan Sumodiningrat (1987:170) menjelaskan bahwa pemberdayaan adalah menciptakan suasana atau iklim yang berkembang, memperkuat potensi ekonomi atau daya yang dimiliki masyarakat. Dalam rangka memperkuat potensi tersebut, upaya yang amat pokok adalah peningkatan taraf pendidikan, kesehatan, serta akses terhadap sumber-sumber kemajuan ekonomi, seperti modal, teknologi, informasi, lapangan kerja dan pasar. Upaya memberikan bantuan terhadap "gepeng" harus dilaksanakan secara terprogram dan 


\section{PEMBERDAYAAN GELANDANGAN DAN PENGEMIS MELALUI BIMBINGAN VOKASI}

DI BALAI REHABILITASI UNIT BINA KARYA YOGYAKARTA

- NOVIE PURNIA PUTRI, MUNIFATUZ ZAHRO'

berkelanjutan bersama pihak terkait sesuai Peraturan Pemprov DIY tersebut.

Di Yogyakarta terdapat balai rehabilitasi sosial terhadap "gepeng", yakni Balai Rehabilitasi Sosial Bina Karya dan Laras (RSBKL) Yogyakarta. Balai ini menghadirkan pelayanan sosial melalui bimbingan vokasional bagi penyandang masalah kesejahteraan sosial masyarakat, seperti gelandangan dan pengemis, pemulung, dan korban penyandang eks-psikotik. Bimbingan vokasional merupakan bentuk kecakapan spesifik yang mengarah pada kemampuan individu dalam bekerja atau mewujudkan suatu karya. Dengan demikian, pemberdayaan masyarakat melalui bimbingan vokasional yang diterapkan oleh balai RSBKL Yogyakarta merupakan bentuk pembelajaran terhadap "gepeng" sebagai pengembangan kualitas mereka sesuai dengan kemampuan yang dimiliki.

Unit Bina Karya memiliki sasaran program satu tahun untuk 50 warga binaan "gepeng" dengan sistem on-off, di mana terdapat periode tertentu terhadap "gepeng" mendapatkan binaan sampai pada tahap terminasi. Warga binaan memiliki identitas, profil, serta latar belakang yang berbeda-beda. Berikut profil dan data WBS untuk kategori "gepeng" di balai rehabilitasi unit Bina Karya per-bulan Juni tahun 2017.

\section{Gambar 1.1 Data WBS Gepeng unit Bina Karya berdasarkan jenis kelamin}

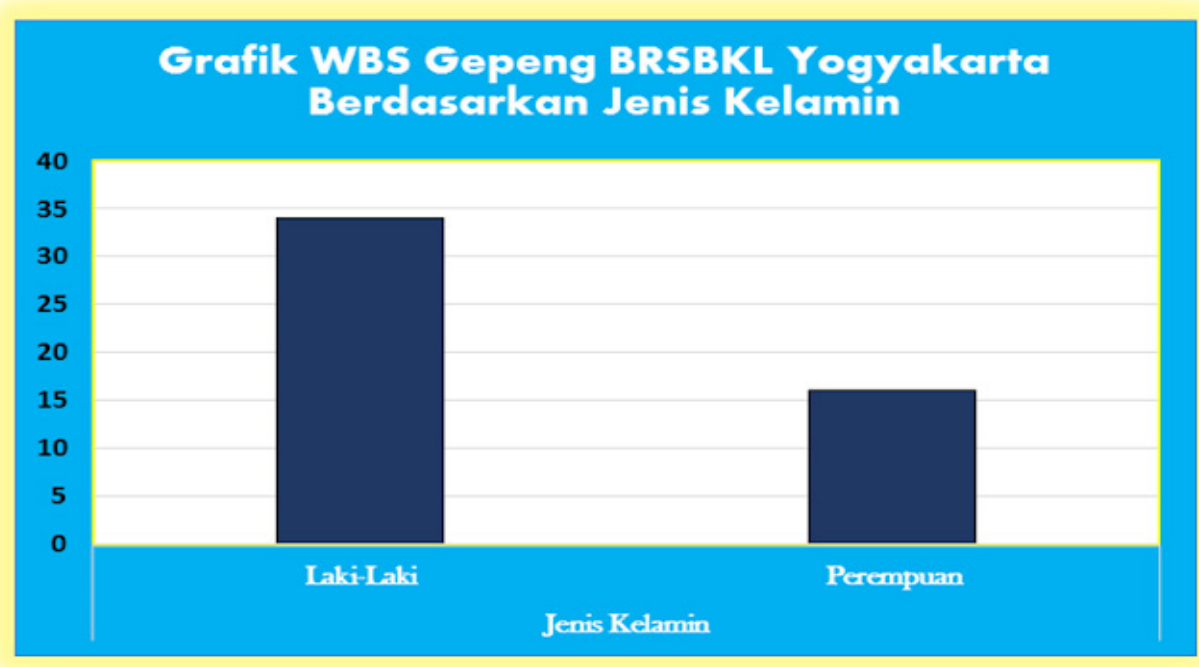

Sumber: Data Administrasi unit Bina Karya 


\section{Gambar 1.2 Data WBS Gepeng unit Bina Karya berdasarkan usia}

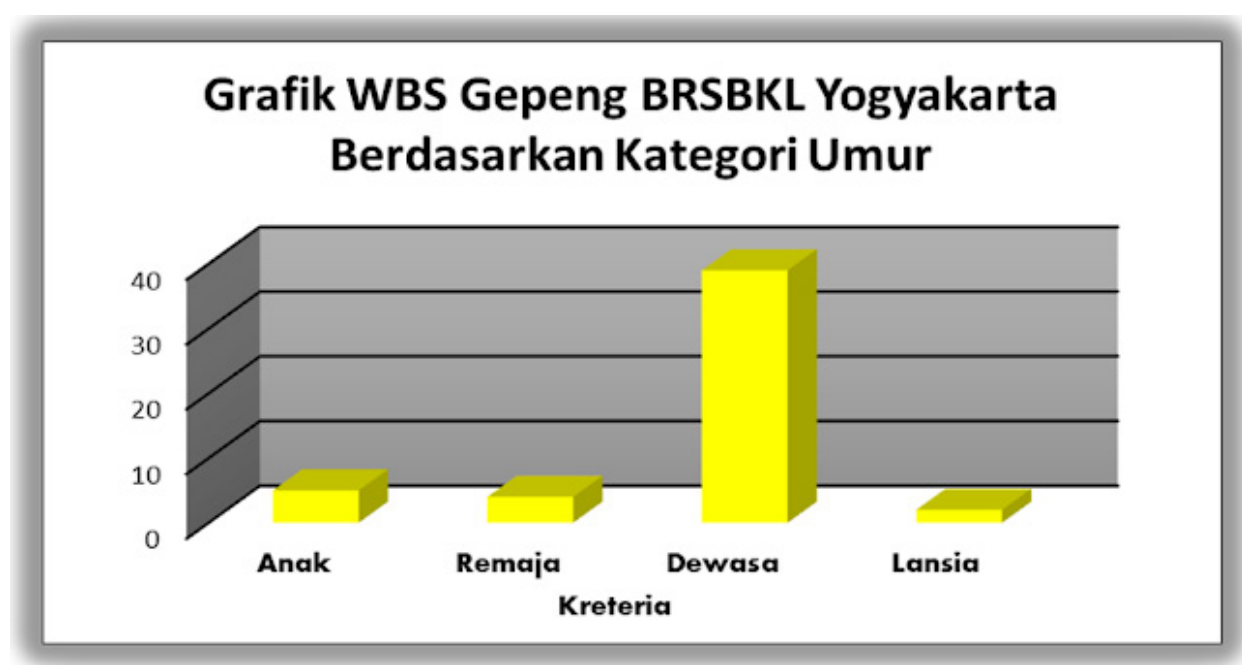

Sumber: Data Administrasi unit Bina Karya

\section{METODE}

Penelitian ini menggunakan deskriptif-kualitatif bertujuan menyajikan gambaranlengkapsifat-sifatindividu, kelompok, keadaan, gejala, penyebarannya, atau untuk mengetahui keterkaitan antar suatu gejala dengan gejala lain di dalam masyarakat. Sugiono (2005:94) mengatakan bahwa metode ini juga disebut penelitian naturalistik sebab sering digunakan untuk meneliti objek alamiah (natural setting). Sukmadinata (2010:8) menyebut bahwa tujuan penelitian ini adalah menggambarkan (deskripsi) sejumlah situasi yang berkaitan dengan peristiwa sebenarnya. Penekanan dari metode ini mencakup proses pembuatan kesimpulan deduktif dan induktif, menganalisis hubungan antar peristiwa melalui perangkat logika ilmiah (Azwar, 2011: 15). Balai Rehabilitasi Unit Bina Laras Yogyakarta dipilih sebagai lokasi penelitian. Sedangkan pekerja sosial di balai tersebut dipilih sebagai informan.

Pengumpulan data pada penelitian ini dilakukan dengan beberapa teknik. Pertama, observasi. Teknik ini menuntut peneliti melakukan pengamatan (observasi) terhadap objek yang diteliti baik pengamatan langsung atau tidak langsung (Juliansyah, 2016: 25). Kedua, melalui teknik wawancara (interview) yakni peneliti menggali informasi dari sumbernya langsung (informan) (Meilia, 2010:28). Ketiga, dokumentasi yakni melalui pencatatan atas peristiwa yang sudah berlalu atau terjadi. 


\section{HASIL DAN DISKUSI}

\section{Pemberdayaan Masyarakat Bimbingan Vokasi yang Diberikan BalaiRehabilitasi Unit Bina Karya Yogyakarta}

Balai Rehabilitasi Unit Bina Karya melayani Warga Binaan Sosial (WBS) dengan jenis permasalahan seperti gelandangan, pengemis, dan pemulung. Bentuk pelayanan meliputi pemenuhan kebutuhan dasar (sandang, pangan, papan, dan kesehatan), penyediaan sarana dan prasarana, pemberian bimbingan fisik, mental sosial, dan rohani, pemberian pelatihan keterampilan, penyaluran kerja, rujukan, dan pemberdayaan ekonomi kreatif. WBS diupayakan dapat mengikuti seluruh bimbingan ini guna membentuk keberfungsian sosialnya sebagai masyarakat pada umumnya. Salah satu bimbingan yang diberikan kepada WBS yakni bimbingan vokasional atau keterampilan. Program ini merupakan tahap lanjut setelah WBS mendapatkan rehabilitasi bimbingan mental, sosial, dan fisik.

Balai rehabilitasi unit Bina Karya memiliki program sistem rehabilitasi "gepeng" berbasis tiga langkah rehabilitasi, di mana program ini merupakan tahapan WBS dari masa persiapan hingga pada bimbingan lanjut. Program ini juga sebagai salah satu bentuk pengembangan model dan merupakan sebuah bentuk inovasi program berkelanjutan guna meningkatkan keberfungsian sosial WBS gelandangan pengemis. Program dilaksanakan kurang lebih satu tahun enam bulan dengan ketentuan: Pertama, rehabilitasi (persiapan) selama delapan bulan. Kedua, langkah persiapan pra dan pasca rehabilitasi yang berlangsung selama empat bulan. Ketiga, proses bimbingan lanjut yang berlangsung selama enam bulan sesuai dengan masa pelayanan yang harus diterima oleh WBS unit Bina Karya.

Pasca memasuki 1 tahun binaan berhasil mandiri dan mengelola keuangan dengan baik, gelandangan dan pengemis diberi bimbingan lanjut selama 6 bulan oleh instruktur kewirausahaan untuk memasarkan produk yang dibuat selama bimbingan vokasional. Sehingga ketika keluar dari balai rehabilitasi, diharapkan WBS bisa bekerja atau berwirausaha, dan tidak kembali menjadi gelandangan atau pengemis. Namun setelah satu tahun pembinaan dan mental belum berfungsi dengan baik, ada toleransi 6 bulan untuk warga binaan tinggal di balai rehabilitasi namun sifatnya bukan lagi menjadi warga binaan tetap. Jika tidak ada perkembangan, terpaksa pekerja sosial melakukan terminasi terhadap WBS tersebut. Untuk mengantisipasi terjadinya warga binaan kembali 
ke jalanan, diberikan bimbingan sosial yang di dalamnya terdapat bimbingan mental dan sosial kemasyarakatan, setelah mental sudah dapat dibentuk kemudian diikuti dengan bimbingan vokasional yang di dalamnya juga diberikan ilmu kewirausahaan.

Pemberdayaan yang diberikan balai ini mencakup keterampilanketerampilan yang nanti bisa digunakan untuk bisa mengentaskan para "gepeng" dari pekerjaan di jalanan. Adapun keterampilan dasar diberikan balai di antaranya kerajinan kayu, las, bertani dan menjahit. WBS diajarkan langsung oleh ahlinya dari jam 08.00-12.00 WIB setiap Senin dan Kamis di ruang keterampilan. Adapun penjelasan dari masing-masing bimbingan, yaitu: Bimbingan Vokasi Las dan Kayu dan Bimbingan Vokasi Menjahit.

Bimbingan vokasi menjahit bisa diikuti oleh laki-laki maupun perempuan WBS. Balai ini memiliki kurang lebih 20 mesin jahit yang digunakan untuk latihan dan produksi. Biasanya para WBS setiap pertemuan diajarkan satu pola jahitan. Dengan harapan nantinya mereka memiliki keahlian dalam bidang menjahit. Produk yang dihasilkan berupa kemeja, lap kompor, taplak meja dll. Produk ini akan dipasarkan ke masyarakat sekitar.

\section{Bimbingan Vokasi Pertanian}

Balai memberikan bimbingan pertanian dengan berbagai jenis tanaman, mulai dari tanaman sayur, buah-buahan, rempah-rempah dan sebagainya. Setiap kali panen, lembaga berusaha untuk memasarkan produk-produk hasil pertanian kepada masyarakat dengan produk yang harganya lebih murah, tetapi memiliki kualitas yang sama.

\begin{tabular}{llcc}
\hline No & Nama Bimbingan Vokasi & $\begin{array}{c}\text { Jumlah WBS yang } \\
\text { Mengikuti }\end{array}$ & Jumlah Instruktur \\
\hline 1 & Bimbingan Las & 7 & 1 \\
\hline 2 & Bimbingan Kayu & 10 & 1 \\
\hline 3 & Bimbingan Menjahit & 20 & 1 \\
\hline 4 & Bimbingan Bertani & 25 & 1 \\
\hline
\end{tabular}

Dari data di atas terlihat bahwa tidak semua WBS mengikuti kegiatan pembimbingan vokasi. Maka apabila terdapatWBS yang tidak mengikuti, pekerja sosial melakukan tindakan peringatan secara lisan sampai pada terminasi di pertengahan program vokasi. 


\section{Faktor Pendukung \& Penghambat Pemberdayaan Gelandangan \& Pengemis}

Bimbingan vokasional terhadap Warga Binaan Sosial (WBS) dijalankan berdasarkan prosedur program balai rehabilitasi unit Bina Karya. Namun, dalam implementasinya tidak lepas dari berbagai kendala, baik dari warga binaan maupun dari balai rehabilitasi.

\section{Faktor Pendukung}

Pertama, Bekerjasama dengan Praktisi, Dalam bimbingan vokasional terhadap warga binaan "gepeng", unit Bina Karya bekerja sama dengan berbagai praktisi yang sudah berpengalaman dalam bidang-bidang vokasi, seperti instruktur menjahit, pertukangan las, pertukangan kayu, pertukangan batu bekerja, bekerjasama dengan Dinas Pertanian Pangan Kota Yogyakarta, dan praktisi-praktisi di bidangnya. Jadi pekerja sosial bekerja sama dengan instruktur yang bersifat personal dan disesuaikan dengan bidang masingmasing dalam mengajarkan bimbingan vokasional.

Pekerja sosial melakukan assessment vokasional pada WBS dengan menentukan bimbingan yang ingin diikuti dan menyesuaikan minat serta potensi yang dimiliki mereka. Tidak ada klasifikasi tertentu dalam menempatkan bimbingan pada warga binaan, jadi mereka tidak dibatasi dalam mengikuti seluruh bimbingan yang diminati. Setelah penentuan minat dan potensi tersebut, kemudian baru ditentukan pemetaan konsep belajar bagi warga binaan mulai dari bimbingan dasar, pembuatan produk sampai pada pemasaran.

Kedua, Bekerjasama dengan Pemilik Usaha, Warga binaan, yang selama bimbingan vokasi mengalami perkembangan, dapat diikutsertakan dalam kegiatan Praktik Kerja Lapangan (PKL) atau yang biasa disebut dengan Praktik Belajar Kerja (PBK). Kegiatan PBK merupakan program yang dicanangkan oleh pekerja sosial unit Bina Karya dengan tujuan utama adalah resosialisasi sehingga warga binaan dapat belajar bermasyarakat melalui bekerja. Kegiatan PBK dilaksanakan selama satu bulan. Untuk sementara ini praktik warga binaan masih ditempatkan di usaha las dan kayu, namun untuk tahun ini juga segera dibuka PBK untuk keterampilan menjahit.

Dalam kegiatan PBK, pekerja sosial bekerja sama dengan tempat usaha yang teregister standar yang registernya hanya bersifat register izin usaha. Pekerja sosial tidak berani memberikan tempat keterampilan yang teregister 
baik di dalam tenaga kerja, mengingat mental warga binaan dengan latar belakang gepeng, tentunya memiliki tujuan untuk menghindari hal-hal yang tidak diinginkan sebagai contoh kasus tindakan mencuri.

\section{Faktor Penghambat}

Pertama, Mental Warga Binaan Sosial (WBS), umumnya, assessment yang ditemukan terhadap "gepeng" adalah faktor mental. Mereka sudah terbiasa mendapatkan uang dengan sistem "tangan di bawah", dengan mental yang seperti itu sehingga menjadikan attitude-nya juga kurang. Yoseph, bagian sarana dan prasarana balai rehabiitasi unit Bina Karya, menyebut bahwa WBS yang paling sulit dibentuk adalah klien dengan latar belakang gelandangan dan pengemis. Karakter mereka sudah terbentuk di jalanan dengan pola pikir bahwa meminta-minta lebih menjanjikan daripada dari bimbingan dan bekerja.

Gelandangan dan pengemis yang mentalnya masih belum dapat berfungsi secara baik masuk ke dalam balai rehabilitasi bukan karena ingin direhabilitasi dan dibina, melainkan menggunakan balai rehabilitasi hanya sebagai sasaran tempat tinggal sementara. Bahkan sudah banyak kasus "gepeng" yang berpindah dari balai rehabilitasi satu ke balai rehabilitasi lainnya. Hal ini kembali pada mental "gepeng" yang justru menganggap hal tersebut dijadikannya sebagai suatu pengalaman dalam dirinya untuk bermukim di setiap balai rehabilitasi yang telah mereka kunjungi, tanpa berfikir untuk benar-benar mengikuti setiap bimbingan yang diberikan dan tidak kembali menjadi "gepeng". Ini yang masih menjadi persoalan pekerja sosial dalam memutus mata rantai "gepeng" dengan kasus seperti itu.

Mental mencuri sebagian "gepeng" belum dapat dihilangkan. Pekerja sosial pernah menemukan kasus WBS mencuri fasilitas barang yang diberikan balai rehabilitasi unit Bina Karya sebagai kegiatan bimbingan vokasional. Bahkan ada suatu kejadian di mana WBS membawa lari kendaraan roda dua milik pekerja sosial.

Persoalan mental "gepeng" ini seperti masalah attitude dan masalah nilainilai sosial. Sehingga meskipun dengan semua pendidikan di unit Bina Karya, WBS tersebut belum dapat secara optimal atau bisa dikatakan pekerja sosial tidak dapat merubah mental WBS secara langsung dalam kurun waktu satu tahun. Hal ini terkadang membuat mereka kesulitan menerima bimbingan pelatihan karena selama ini sudah memiliki mental peminta-minta. 


\section{PEMBERDAYAAN GELANDANGAN DAN PENGEMIS MELALUI BIMBINGAN VOKASI \\ DI BALAI REHABILITASI UNIT BINA KARYA YOGYAKARTA}

- NOVIE PURNIA PUTRI, MUNIFATUZ ZAHRO'

Kedua, Penolakan WBS terhadap Kegiatan Bimbingan Vokasional, pada kasus ini terdapat beberapa WBS yang menolak untuk diberikan bimbingan maupun pembinaan, karena kondisi mental antara pikiran dan perasaan yang dihadapi mereka masih belum dapat dikendalikan. Hal ini yang membuat WBS merasa enggan mengikuti kegiatan. Dalam wawancara penulis dengan Titik (instruktur menjahit), terdapat WBS yang secara berkelompok bersepakat untuk tidak mengikuti kegiatan bimbingan vokasional dengan alasan kegiatan bimbingan tidak menyenangkan dan tidak sesuai dengan harapan WBS tersebut. Adapun penolakan WBS lainnya dengan alasan bosan terhadap kegiatan bimbingan vokasional.

Pekerja sosial memahami bahwa tidak mudah bagi mereka dapat menerima langsung bimbingan dan pembinaan, maka pekerja sosial berupaya untuk selalu memberikan motivasi dengan memberikan reward pada setiap kegiatan yang dilakukan oleh mereka, dengan tujuan WBS bersedia mengikuti kegiatan-kegiatan berupa bimbingan maupun pembinaan khususnya dalam bimbingan vokasional.

Ketiga, Kurangnya Tenaga Pekerja Sosial,selain tugasnya dibalai rehabilitasi, pekerja sosial memiliki tugas kerja di lapangan seperti kegiatan home visit dan assessment awal. Sehingga tidak setiap waktu pekerja sosial berada di balai rehabilitasi. Pekerja sosial juga berperan sebagai fasilitator dalam mendampingi bimbingan vokasional terhadap WBS. Namun dalam beberapa waktu, pekerja sosial tidak dapat mendampingi kegiatan karena bersamaan dengan kunjungan maupun tugas-tugas lain di luar balai rehabilitasi. Sehingga pendampingan terhadap WBS diwakilkan oleh bagian administrasi untuk membantu dalam berjalannya kegiatan bimbingan vokasional di unit Bina Karya.

Keempat, assessment vokasional kurang mendalam. Pekerja sosial dalam melakukan assessment vokasional hanya bersifat lisan. WBS hanya ditawarkan secara lisan terkait berbagai jenis pelatihan keterampilan dalam memilih kecenderungan potensi bidang yang diminati. Soal utamanya, assessment vokasional tidak mendapat dukungan fasilitas yang cukup memadai. Akibatnya, bimbingan vokasional WBS hanya "asal memilih" sehingga komponen di setiap keterampilan tersebut akan melebihi kuota.

Dengan assessment vokasional yang seperti itu, sehingga bimbingan menjadi kurang efektif. Hal ini ditunjukkan dengan adanya warga binaan yang tidak komitmen dengan ketentuan bimbingan yang dipilih sebelumnya, yaitu 
WBS ingin mengganti pelatihan keterampilan lainnya dari pelatihan yang telah diberikan sebelumnya. Dalam melakukan perubahan pembinaan pada WBS ini pun tidak dapat dengan mudah dilakukan, mengingat sarana dan prasarana juga menyesuaikan anggaran dari pemerintah. Karena untuk memulai pembinaan dari awal lagi, pekerja sosial akan menambah anggaran baru lagi.

\section{KESIMPULAN}

Dari pembahasan tersebut disimpulkan bahwa pemberdayaan terhadap gelandangan dan pengemis dalam menerapkan bimbingan vokasional dilakukan oleh masing-masing praktisi yang kompeten dalam bidangnya, baik dalam bimbingan ketrampilan las, kayu, menjahit, dan pertanian. Pembinaan vokasional tidak terlepas dari kendala internal maupun eksternal yang menyebabkan program kurang berjalan maksimal. Kendati demikian, selama program berlangsung pekerja sosial juga tetap memprioritaskan pembinaan mental sebagai assessment utama dalam pelayanan rehabilitasi terhadap "gepeng". Mengingat permasalahan paling utama "gepeng" adalah mental yang menyebabkan sempitnya pola berpikir.

\section{DAFTAR PUSTAKA}

Azwar, S. (2011). Metode Penelitian. Yogyakarta: Pustaka Pelajar.

Bina Karya. (2017, 8 Agustus). "WBS Gelandangan Pengemis Balai RSBKL DIY Per Juni 2017”. Diakses dari http:/brsbkl.jogjaprov.go.id/2017/08/wbsgelandangan-pengemis-balai-rsbkl.html

Juliansyah, N. (2016). Metode Penelitian Skripsi, Tesis, Disertasi, dan Karya Ilmiah. Jakarta: Kencana Prenada Media Group.

Peraturan Pemerintah Republik Indonesia Nomor 3 Tahun 1990 tentang Perubahan Atas Peraturan Pemerintah Nomor 16 Tahun 1974 Tentang Pelaksanaan Penjualan Rumah Negeri Sebagaimana Telah Diubah Dengan Peraturan Pemerintah Nomor 38 Tahun 1982.

Peraturan Pemerintah Republik Indonesia (PP) Nomor 31 Tahun 1980

(31/1980) tentang Penanggulangan Gelandangan Dan Pengemis

Peraturan Daerah (Perda) Provinsi Daerah Istimewa Yogyakarta No. 6 Tahun 2011 tentang Perlindungan Anak Yang Hidup Di Jalan

Susanti, M.N.I. (2010). Statistik Deskriptif dan Induktif. Yogyakarta: Graha Ilmu. Sugiono. (2005). Memahami Penelitian Kualitatif. Bandung: Alfabeta. 
- NOVIE PURNIA PUTRI, MUNIFATUZ ZAHRO'

Sukmadinata, N.S. (2010). Metode Penelitian Pendidikan. Bandung: PT. Remaja Rosdakarya. 